\title{
The Evolution of Russian Institutions of Agricultural Loan: From Domination to Systemic Approach
}

\author{
Oleg Usherovich Avis ${ }^{1}$ \\ 1 Department of Banks \& Bank Management, Financial University under the Government of the Russian \\ Federation, School of Management, Moscow, Russian Federation \\ Correspondence: O. U. Avis, Department of Banks \& Bank Management, Financial University under the \\ Government of the Russian Federation, Moscow, Russian Federation. Tel: 7-495-615-72-75. E-mail: bibm@fa.ru
}

\author{
Received: March 11, 2015 Accepted: April 10, 2015 Online Published: May 25, 2015 \\ doi:10.5539/res.v7n10p85 URL: http://dx.doi.org/10.5539/res.v7n10p85
}

\begin{abstract}
A detailed study of the key political and economic declarations and regulations related to the attempts to establish and develop agricultural loan system in the country, allows to make paradoxical conclusion: in the context of formation of market relations in modern Russia and establishment of adequate institutions, the essence of such system was reduced to setting up a monster institution, a monopolistic institution, a quasi-public banking organization with its rights and responsibilities to include all items typical for a system of that kind in general.
\end{abstract}

Keywords: bank, agriculture loans, risk management, banking sector

\section{Introduction}

We believe that the phenomenon of existence of a bank with the share held by the government, such as Rosselkhozbank (Russian Agricultural Bank) can be explained by the coincidence of many factors, including, first of all, old thinking, habitual approaches to system functioning, and excessive commitment to traditional values and institutions.

The history of assigning the meaningful legal status of an institution with unique nature, unique tasks and unique importance to the Russian Agricultural Bank demonstrates lack of understanding, inconsistency and contradictory nature of all legal and corporate rules used by the bank to guide its activity up to the present day.

There are many reasons to claim, from institutional and strategic point of view, that the bank's philosophy at present is a patchwork comprised of numerous ideas and hopes of different interest groups, being at the same time the reflection of these or those epochs of political and corporate imagination in modern history of agricultural loan system in Russia. (Bazarya, 2002)

There is no doubt that one of the reasons behind the institutional dead end in which the bank is at the moment lies in its following doubtful strategic objects in the process of its development.

Thus, when formulating the state credit policy in agriculture, the bank believes it would be strategically correct to achieve "adequate capitalization and funding potential in the interests of national agricultural loan system that, at the current stage of social and political development, should be consolidated around the Russian Agricultural Bank". (Chayanov, 1917)

At the same time, as determined in one of its development strategies, it is important for the bank to identify new areas of credit business, i.e. shift from narrow to wide programs that would cover all stages of production, storage, processing and sale of agricultural products. (Izambert, 2002)

The bank believes that this requires fundamental changes in the approaches of the Bank of Russia and banking community to creditworthiness assessment and security of loans granted to the borrowers representing new top-priority areas of credit support. (Yanbykh, 2013)

In the bank's opinion, significant effect would be produced by vesting a number of controlling and expert functions in it aimed to reduce construction costs both at the state of project solution selection and design, and in the process of production facility construction and commissioning.

Among other functions to be vested in it, the Bank attaches great importance indeed to its engagement in fostering real conditions for a fast, cheap and complex formation of land mortgage lending system. 
It is clear that by offering correct content-wise ideas, the bank regards itself as frontline worker in implementing them: isn't it the unequivocal confirmation of the bank's claims to play the role of a "bank-system"?

However, actual values of, and trends in, the bank's key performance indicators suggest that such structure in the form of a specialized farm lending institution has been unable already for a long time to sustain the varied and universal nature of business, to which is has been committed, and its current development model to a considerable extent contradicts the objectives of improved performance based on intensive development.

Nevertheless, in this context, proposals have been voiced in recent years at all levels of bank hierarchy and industry-specific policy as to the privatization of the Russian Agricultural Bank as an important stage in its development.

\section{Analysis of Factors and Impact of the Implementation of the Alternative Bank Development Model Based on the Bank's Possible Privatization}

The idea to privatize the bank emerged from time to time and was discussed at the highest level.

In general, the following stakeholders can be interested in the bank's privatization:

- The government - to be able to further pursue their lending policy to drive the agricultural sector development and gain maximum possible profit from the disposal of the part of the shares in the bank;

- The agricultural sector - to preserve a reliable and stable agricultural bank;

- Potential investors - to enable effective bank management and receive maximum return on their investments in its capital through dividends, and long-term and relatively cheap resources for the development of their affiliated industries.

If privatization assumes that the bank will be used as the key bank for the agricultural sector, then such factors as the bank's value and the benefits received by the government from the sales of the shareholdings become of secondary importance. Being state-owned, i.e. totally owned by the government, means the following:

- Inherently low return on equity and assets of the bank;

- Strategically narrow diversification of investments, with an overwhelming share falling to its target customer group in the agricultural sector, which is characterized by increased risks;

- Development of banking business technology that takes into account the specifics and the needs of the bank's target customers;

- Maintenance of a wide regional network that is inherently costly and caters for target customers, which means that its performance is low.

In this context, privatization becomes rather problematic, since at present it is practically impossible to find a strategic investor or a group of investors having the vision of the bank similar to that described above.

It is to be recalled that the bank's ratings are based not on its margins or fair market value, but on its state nature, direct influence of the government on its operations, and its readiness to assume responsibility, should any problems arise as to the fulfillment of the key strategic tasks.

In case the bank's privatization assumes selling its shares to other investors, there is no doubt that the market value appraisal of its shares will reflect the factors that will have a significant lowering effect on its value, such as assets exposed to risk, large-scale and costly regional network, non-competitive level of technology penetration and service offer. (Burakov, 2014 a; 2014b) To increase the market value of the bank's shares, significant amount of time will be needed to mitigate or eliminate such factors, which will require no so much time as additional expenses. However, the need for drastic change in the existing focus will be the main negative aspect in the circumstances. Under such scenario, the bank certainly will not be focused on its current key customers. This means it will cease to be an agricultural bank.

Currently, the Russian Agricultural Bank, in addition to Sberbank, is a core financial institution catering for agricultural organizations and enterprises, and it dominates, in terms of both number and volume of loans, within the sector of loans to rural SMEs, individual farmers and agricultural cooperatives, including credit cooperatives.

However, the bank's operations progressively demonstrate the signs suggesting that it loses its previous dynamics in terms of number and volume of loans, and that its quality parameters and performance indicators are deteriorating.

The bank's regional structure, represented by a wide network of rural additional offices, is clearly underloaded and inefficient in terms of return and margin. 
The bank's loan portfolio is focused primarily on its target industry, the national agricultural sector, i.e. it is insufficiently diversified and is characterized by the unique concentration of risks: on the one hand, the risks are generated by the factors that determine the specifics of the agricultural sector, on the other hand, they arise in the process of lending in order to meet industry-specific needs. At that, the bank has no special capabilities to mitigate or hedge such risks, while the prudential compliance standards applicable to the bank correlate very little with the ability of adjusting them based on the existing financial rehabilitation rules for a considerable portion of its borrowers.

To a considerable degree, the bank's lending policy is characterized by lack of independence in terms of the ability to choose borrowers and lending mechanisms, due to the need to strictly follow the targets laid down in the governmental top-priority and target programs. In that, the addressless character of geographical or industry-specific focus of the key lending directions is revealed, as well as their discrete and inadequate elaboration and justification, and disregard for the need to support the entire process chain, including production, processing and sale of agricultural products. This considerably weakens the ability to achieve the end-to-end lending efficiency based on true synergy, and triggers the shortage of financial resources of the bank that are usually generated as funds move on accounts of the projects and entities financed through lending, and the need arises for the bank to compensate such shortage through considerable appreciation of external borrowings.

Such specific collaterality of the bank's role in its long-term lending policy, being implemented in a great measure based on directives and recommendations issued by the federal or regional authorities responsible for the agricultural sector, very often leads to the formation of investments portfolio, which, with the deterioration of its quality, constitutes exceptional problem for the bank. Usually, in cases of fraudulent bankruptcy of borrowers and hidden dissipating of assets, the support from the federal or regional authorities is either delayed or is not given at all.

Such reasons may also include the uncertain status of the bank. A development bank, a universal bank, a bank acting as a government agent for the implementation of target programs and projects - all these actual characteristics of the bank, in fact, hardly correlate with each other and cannot be tied together in principle. These are different strategic bank development models, and their simultaneous implementation makes the bank unable to advance. Moreover, they largely contradict each other, thus causing direct damage to the bank.

In this connection, we need to emphasize the bank's actual status as an institute for comprehensive and term lending to meet the seasonal needs in plant growing when performing spring and autumn field works. In the situations of recurrent climatic disasters, such as droughts, floods, pest outbreaks, etc., the bank's lending portfolio is destined to be troublesome. It is not characterized by systemic nature and remains poor in quality, even with central and regional government guarantees or guarantees provided by regional guarantee and security funds. The restructuring of such loans carried out according to the Resolution of the Government is in no way accompanied by financial rehabilitation measures for the borrowers stipulated by law, and has no impact on the assessment of such measures by the bank supervisors.

Loan portfolio deterioration and the need to allocate considerable loan loss provisions are among the key reasons why the bank owner has to continuously increase its capital and why further loan portfolio growth does not compensate losses; therefore, the bank's return on equity and return on assets remain on very low levels, considerably falling short of not only general commercial banks, but also of other banks owned by the federal government.

At that, it is necessary to bear in mind that loan portfolio maintenance requires considerable time and financial costs and creates an additional load on the bank's front office servicing a great number of small and medium-sized borrowers. Instead of streamlining its workflow, engaging a number of intermediaries and outsourcing certain functions, the bank established a "self-sufficient farm" consuming the same huge amounts of funds without adequate return. (Burakov, 2014c) So, a considerable portion of real margins from borrowing funds and investing them in appropriate projects and programs are consumed by the costs incurred to maintain a huge inefficient regional network and big non-technical staff of the head office.

In such a situation, it is necessary to point out once more that bank privatization is impossible, since a serious investor will set himself a task to restructure the bank completely, to abandon its focus and current organizational and regional structure, and to reduce its operating expenses considerably. In principle, it is clear and reasonable. The consequences for the agricultural sector and the country in general will be a good deal worse in case the established institutional farm lending system is lost. 
Nevertheless, changes are necessary. They are urgent and unavoidable. The only question is what shape they need to take, which institution needs to be chosen, and what strategic goals need to be set again to solve such an important task.

All analysts agree that it's high time to restructure the Russian Agricultural bank.

\section{On the Restructuring Options for the Country's Key Agricultural Bank}

We think that total reengineering of the bank is the best option available. It should be based on the commitment to minimize possible losses, restructuring its assets and liabilities for enabling the bank's existence, dividing difficult-to-combine functions and providing the respective institutional framework to for such functions to be performed in a more successful way.

The steps to reengineer the Russian Agricultural Bank should be logical, consistent, complex and realistic. First of all, it requires the comprehensive and unbiased audit of actual state of things, which should be carried out by independent auditors and officers from public authorities, such as Ministry of Agriculture, Ministry of Economy, Ministry of Finance, Accounts Chamber and Bank of Russia.

The bank's organizational and functional structure should also be subject to comprehensive audit to verify its adequacy with regard to the bank's objectives and determine its load and efficiency levels.

Based on such audit the bank's current functions should be divided into blocks of independent tasks, and outscoring of such blocks to independent specialized companies should be considered.

A new structure should virtually represent the system of agricultural loan institutions and should include the Russian bank for agricultural sector development, regional development bans, corporate bank lending system, Russian land mortgage lending bank, and regional land mortgage lending banks, regional agricultural investment companies, and agency for toxic agricultural assets (toxic assets bank). (Smirnova, 2009)

It is suggested to transfer some part of the equity of the Russian Agricultural Bank to regional development banks, together with the genuinely functioning long-term assets and liabilities.

Transfer of the portfolio of troubled and non-performing loans to the newly-created agency for toxic assets should be accompanied by the transfer of the respective amount of capital to the agency to be able to restructure such loans and undertake, whenever possible, financial rehabilitation or real M \& A.

Regional offices of the Russian Agricultural Bank have to be closed or sold to other federal or regional banks, with the stipulated condition that they will be used to provide services to agricultural organizations and companies.

The option for the reengineering of the Russian Agricultural Bank, as described above, is our vision of the problem and its solution. In addition, great importance is attached currently to the idea of bank transformation, with possible options and alternatives widely discussed by the Government of the Russian Federation and the officials from many ministries offering their own solutions. (Trushin, 2011)

In 2013, the information appeared that the Russian Agricultural Bank may be divided into two structures, with its further transformation into an institute supporting agriculture and privatization of the remaining part of the bank. However, the government considered that it would be premature to transform the bank into a state corporation, as well as excluding it completely from privatization list.

Still, it is not clear how the agriculture-supporting institution will function in the future. Possible alternatives include following the model of the French bank Credit Agricole that combines the functions of universal and agricultural bank.

Many experts believe that the Russian Agricultural Bank is inefficient as a credit institution characterized by a considerable volume of toxic assets and addressing its problems using budgetary receipts in its authorized capital.

The transformation of the bank into a development institution will require the redemption of the bank's subordinated debts by the bank and heavy expenditures coupled with the need to address the problem of toxic assets.

While some experts believe that toxic assets could be transferred to the Deposit Insurance Agency as an alternative to toxic assets redemption, such assets estimated at RUB 140 billion in total appear to be overwhelming for the Agency.

Obviously, the task of a dynamic shift from the functioning of a dominant institution to creating a much-needed agricultural loan system will require considerable efforts, time and costs. 
In addition to the proposed concept of reengineering of the Russian Agricultural Bank, it is also important to formulate the concept of developing other components of the future system.

\subsection{Prerequisites for Developing Agricultural Loan System}

Why can the considerable part of rebukes addressed to the agricultural sector, such as calling it a "black hole", be regarded as justified? Why does the government in Russia have to write off agricultural debts from time to time, regardless of the specifics of the current social and political system? Can this be the recognition of the fact that the agricultural sector still gives much more to society and economy than it earns, and the society and the government, with the same frequency, shall (or are destined to) give back to the agricultural sector all that has been unfairly taken away from it, if only in the form of debts being written off?

It is clear that the fixing of the above-mentioned characteristics of creditworthiness of agricultural enterprises and concentration of such qualities in relations with several major financial institutions, and even in a separate banking system, will eventually cause huge problems for them and spell their collapse.

In this regard, a question should be asked whether there is any sense in strengthening, transforming, modernizing, improving and supporting such systems using administrative and economic means, if such prospects stand out for it?

Maybe this problem could be better addressed by traditional universal banks that are obliged to diversify their risks ideologically and commercially and "put their eggs in many baskets"?

It is absolutely not clear why the industry that supplies people with food on a daily basis, feeling a steady demand for its products and involving tens of millions of people in its production process, has always been forced to face chronic deficit of financial and monetary means on an equally large scale.

Can the efficient agricultural loan system exist in the context of inefficient agricultural production, inconsistent state policy and excessive debt load on domestic agricultural industry?

Evaluating the qualitative and institutional adequacy of the current lending mechanism, we should state again that an integral credit and financial system for agricultural producers still does not exist in Russia.

Such radical conclusion is based on the following facts:

- Government institutions dominate in the agricultural loan sector, both in terms of agricultural machinery and equipment lease, and in terms of agricultural technologies, while large-scale injections of resources and capital are almost not available for numerous regional and municipal banks that have worked and are still working actively with agricultural producers and other agents in the agricultural sector. Due to this very reason, there are no specialized agricultural sector development institutions available;

- Weakening as to the positions of the system of agricultural credit cooperatives, the revival of which was actively assisted at the turn of the centuries by the representatives of major cooperative credit institutions in Europe;

- Zero dynamics as to the institutional and infrastructural development of land mortgage lending system that has not managed so far to overcome its pilot stage;

- Rejection of the opportunities to significantly build up the business in the agricultural sector by Russian insurance companies;

- Weak development of investment companies that is unable to raise funds for national agricultural sector;

- Inconsistent, inadequate and inefficient legal framework and practice in the field of financial rehabilitation of agricultural producers;

- Current imperfect system of budget subsidies provided to cover the interest on agricultural loans received by agricultural producers from commercial banks or agricultural credit consumer cooperatives, when subsidies often lose their target orientation and stimulating qualities;

- Low efficiency of operations as to the formally created guarantee and security funds, which narrows down potentialities of loans provision to agricultural producers.

With such characteristics, the organization of agricultural lending in Russia today, which requires considerable funding in terms of volumes and period of use, is unable to consolidate cash flows generated in national agricultural sector and, as we believe, will not support steady development of agricultural lending, agricultural banks, agricultural sector and the country in general.

It is necessary, as soon as possible, to start working out real, non-declaratory a strategy of creating legal, economic and intuitional environment to foster national agricultural loan system, which will make it possible to determine its 
legal status, to formulate the conditions for participation of financial institutions and support of their development, including commercial banks and credit cooperatives, and to adapt, respectively, with due regard for the specifics of the target customers, a number of civil, banking, financial and tax laws.

All the more so, as the current situation urges on such actions connected with the possible transformation of the Russian Agricultural Bank, the country's leading agricultural lending institution.

The creation of other efficient institutions incorporated in the agricultural loan system requires developing the respective concepts. In this connection, it seems important to identify the development vector of some significant agricultural loan institutions.

\subsection{The Need to Create a Complex of Agricultural Loan Institutions}

We would like to dwell on the problem of legal and institutional framework of agricultural loan system that would be adequate to national economic development targets.

The existence of small agricultural producers in such system, that account for considerable production volumes, and the objective need to ensure their survival and future prospects in the context of Russia's accession to the WTO, as well as tougher competition in food markets, required, in addition to large-scale budget and economic support measures, fostering legal and economic conditions for consolidation of their production potential based on cooperation, including its representation in the financial sector. Currently, this task is being addressed, though not very successfully and not on a large scale, only by agricultural credit consumer cooperatives, since, according to the applicable Russian law on banks and banking activities, credit institutions may operate only in the form of business companies, although credit organizations in the form of credit cooperatives and cooperative banks have been successfully operating all over the world for a long time.

At that, it is important to keep in mind that foreign cooperative banks organize their activity based on cooperative principles, and in this way they turn out to be more reliable than joint stock banks, they are less exposed to risks or unbridled pursuit of profits and share price growth.

Therefore, there is urgent need to make amendments to Russian banking laws, which would complement the status of a legal entity of credit organizations by the form of cooperatives and establish special supervisory and regulatory approaches to them. If granted legal status, cooperative banks, at the initial stages of their establishment and development, will receive large-scale financial support from the government or state-controlled systemic banks and development institutions.

In this way, the idea will be materialized as to ensuring a level playing field for credit institutions that have different scale, operating parameters, capitalization and legal status, but are able to operate in the credit market rather efficiently.

All this will require stage-by-stage approach in addressing challenges facing the future system of cooperative agricultural loans.

At the first stage, it is suggested to take a set of measures to improve the intra-corporate and legislative mechanism of operations of the existing agricultural credit consumer cooperatives of all levels, to make them attractive for investments and considerably increase their credit ratings.

Simultaneously, it is necessary to use the opportunities for the representatives of agricultural credit cooperatives of all levels to acquire interest in the capital of some regional commercial banks to ensure external transformation of joint-stock principles of their operation into cooperative principles, which are reflected in their articles of association, within the applicable banking laws, as well as to provide the opportunity for practical tests of their performance efficiency within the new status. For the purpose of study and practical application of experience in organizing similar foreign cooperative credit systems, it is necessary to share experience with the leading European cooperative banks and credit cooperatives.

At the second stage, it is suggested, with due account for the experience of operation of commercial banks having a cooperative nature, according to their articles of association, to develop a number of proposals that will introduce significant amendments to national cooperative, banking and tax legislation. Their adoption, supported by farming and cooperative community, deputies and regional authorities, will make it possible to lay the foundation to create the final element of the agricultural cooperative credit system, i.e. the agricultural bank of cooperative credit.

Land mortgage lending, the potential of which is practically not realized in today's Russia, is of special importance among the economic and legal tools available to support the agricultural sector with money and financial means. Within a considerable part of Russia, agricultural land in itself is largely undervalued, unattractive for the market, and it is considered risky and illiquid by banks. This issue involves a whole range of economic, legal, financial, 
banking, property and institutional aspects requiring close attention from all stakeholders engaged in land relations and the associated matters. Elaying the solution of the land issue in Russia maybe rife with the most severe economic and social consequences, which will definitely affect land mortgage lending institutions.

The implementation of pilot land mortgage programs in Russia by state-owned banks revealed the legislative issues affecting the development of agricultural land mortgage lending and bank lending technologies. The fact that house mortgage lending is much more developed in the country affected the development of mortgage lending framework, which takes little account of the specifics of land mortgage relations and agriculture itself, in particular, the fact that, in agriculture land is the key asset, not only the property evaluated as a possible loan security. For the purpose of lending, special attention needs to be paid to a specific legal treatment manifested in target use, terms and conditions applicable to possession, use and disposal and, consequently, a special levy of execution and sale procedure.

The legal factors currently restraining the development of land mortgage lending in Russia include the following:

1) Imperfect legal procedure for levy of execution and transfer of title to land in case it is sold through an auction;

2) Absence of clear legal definition of the possibility for partial mortgage of land without changing its boundaries, as well as unclear regulations governing the mortgage of jointly owned lands and the related procedure of levy of execution;

3) Weak legal protection of the interests of mortgagor and mortgagee in case of forced disposal of mortgaged land or any part thereof for state or municipal needs;

4) Inconsistency in the approaches to levy of execution against mortgaged land with buildings and structures thereon, as laid down in the Civil Code and the Law on Mortgage (Real Estate Mortgage);

5) Imperfect procedure for forming land plots and their documentary and contractual formalization;

6) Legal restraints and discrepancies in banking, financial, tax and other laws related to the issue and sale of mortgage-backed securities, standardization of land mortgage loans, and the related loan granting and servicing procedures;

7) Poor land inventory and disregard for the specifics of agricultural land mortgage lending when banks draft loan agreements;

8) No reliable legal and economic mechanism to grant banking loans to finance land lease rights to be used as a security.

Addressing the challenges described above will fill land mortgage lending in Russia with totally different contents and will allow to make it investment-attractive both for Russian and foreign banks and investors, and will also open up great opportunities for land owners and tenants to undertake significant technical and economic transformation of the production activity on such lands by raising so-much-needed long-term financial resources.

The task of raising considerable (in terms of volume), relatively cheap (in terms of cost) and long-term credit resources to develop agriculture in Russia currently encounters some obstacles connected both with the general financial and economic problems in the world, as well as with unique national factors.

The development of lending processes is objectively hindered both by cautious approach of most commercial banks to granting loans to agricultural producers due to considerable risks and the resulting increased and tougher requirements to bank lending mechanisms and capital adequacy, which are imposed by the prudential authorities, and by the objective considerable deficit of relatively cheap and long-term funds faced by banks. In addition, difficult financial position of most agricultural producers, low production profitability even with state subsidies, their existing borrowings (considerable even against annual production volumes and sales), and weak or missing security of their current and future obligations to banks - all these factors hindering lending, affect current state of many agricultural players and their development prospects.

Globalization of the world's financial markets and the related process of deregulation of the global financial and banking system, which were recognized as the most important causes of the global financial crisis, required unprecedented measures from the part of the supervisors in most global banking systems, including tougher requirements to bank capital formation, loan loss provisions and stronger risk management, which cannot but affect loans for the real sector of economy, resulting, first of all, in decrease in the banks' abilities to grant loans to the real sector. 


\section{Conclusion}

Nevertheless, as has been mentioned above, agricultural production always needs borrowings on a permanent basis, therefore, the respective credit support should be extended. Even given that the debt load of agricultural producers is always high and, possibly, sometimes it is at a critical level from the point of view of banking supervisors.

No doubt, the same approach should be adhered to in Russia, although the specifics of its agricultural sector development includes, inter alia, a large number of restructured debts arising due to objective reasons, in particular, as a result of unfavorable weather conditions that have been observed over the past years.

\section{References}

Klementyev, P. (2013, May, 17). Rosselkhozbank mogut razdelit na bank $i$ institut razvitiya APK [Rosselkhozbank may be divided into a bank and an agriculture development institution]. Gazeta. ru.

Bazarya, M. P. (2002). Zemelnye otnosheniya i sozdanie selskoy kreditnoy sistemy [Land relations and creation of a rural lending system]. DiK, 7.

Bronevitsky, P. (2011). Gosudarstvennoye kreditovaniye selskogo khozyaystva: Rossiyskiy opyt [Governmental agricultural lending: Russian experience]. Rodina [Motherland], 1.

Burakov, D. V. (2014a). Credit Cycles \& Debt Restructuring: Refining Theoretical Flaws. Review of European Studies, 6(4), 1-11. http://dx.doi.org/10.5539/res.v6n4p1

Burakov, D. V. (2014b). Do Methods of Estimation Affect Credit Risk Osccillations? Mediterranean Journal of Social Sciences, 5(20), 114-120. http://dx.doi.org/10.5901/mjss.2014.v5n20p114

Burakov, D. V. (2014c). How to Measure Herd Behavior on the Credit Market? Mediterranean Journal of Social Sciences, 5(20), 516-521. http://dx.doi.org/10.5901/mjss.2014.v5n20p516

Chayanov, A. V. (1917, summer). Chto takoe agrarny vopros [What the agrarian issue means]. M.

Dmitriev, I. V. (2011). Osobennosti i perspektivy razvitiya i kreditovaniya selskokhozyaystvennykh predpriyatiy [Lending and development specifics and prospects of agricultural enterprises] (Abstract of a thesis for a Ph.D. degree). Moscow.

Gosudarstvennoye kreditovaniye agrarnoy sfery ekonomiki [Government lending in the agricultural sector]. (2010). Source: APK: Ekonomika i Upravlenie [Agriculture: Economy and Management], 1.

Jean-Loup, I. (2002). CreditAgricole vne zakona [Credit Agricole out of law] (Translation from French). M.: RIA-ARP.

Khoroshemu banku status meshayet. (2010, November 9). Schetnaya palata predlozhila RSKHB stat institutom razvitiya [A good bank blames its status. The Audit Chamber proposed RSKhB to become a development institution]. Kommersant, 206(45).

Ministry of Agriculture of the Russian Federation. (2013). National 2012 report on the progress and results of implementing the State Program for Agriculture Development and Regulation of the Markets of Agricultural Products, Raw Materials and Food for 2012-2020. Moscow.

Ponomareva, A. E. (2006). Problemy i osobennosti kreditovaniya selskokhozyaystvennykh predpriyatiy [Problems and specifics of agricultural loans]. Sovremennyye problemy nauki i obrazovaniya [Modern problems of science and education], 4, 116-118.

Poshkus, B. (2011). Ternistiy put sistemy kreditovaniya selskogo khozyaystva Rossii [The thorny path of agricultural loan system in Russia]. Ekonomika selskogo khozyaystva Rossii [Economy of agriculture in Russia], 2, 27.

RSKHB ne otpuskayut s rynka [RSKhB is not allowed to quit the market]. (2014, February 24). Vedomosti.

RSKHB propisano protivoyadie [Antidote prescribed to RSKhB]. (2014, April 22). Vedomosti.

RSKHB prosit otmenit privatizatsiyu. (2013, April 09). Bank khochet poluchit status goskorporatsii [RSKhB asks to cancel privatization. The bank wants to get the status of a state corporation]. Kommersant, 61(5092).

Russian Banking Sector Development Strategy for the period until 2015. (2015). Moscow, Government Press.

Smirnova, T. S. (2007). Obespecheniye dostupnosti kreditnykh sredstv dlya selskokhozyaystvennykh tovaroproizvoditeley $v$ Rossii [Ensuring the availability of loans for agricultural producers in Russia] (Abstract of a thesis for a Ph.D. degree). Moscow.

Trushin, Yu. V. (2011). Oroli sistemy kreditovaniya v ekonomicheskom regulirovanii selskogo khozyaystva 
[About the role of lending system in economic regulation of agriculture]. Moscow.

Yanbykh, R. O. (2013). Kontseptsii razvitiya kooperatsii na sele na period do 2020 goda [About the concept of cooperation development in rural areas for the period until 2020]. Ekonomicheskoye razvitiye Rossii [Economic Development of Russia], 5 .

\section{Copyrights}

Copyright for this article is retained by the author(s), with first publication rights granted to the journal.

This is an open-access article distributed under the terms and conditions of the Creative Commons Attribution license (http://creativecommons.org/licenses/by/3.0/). 